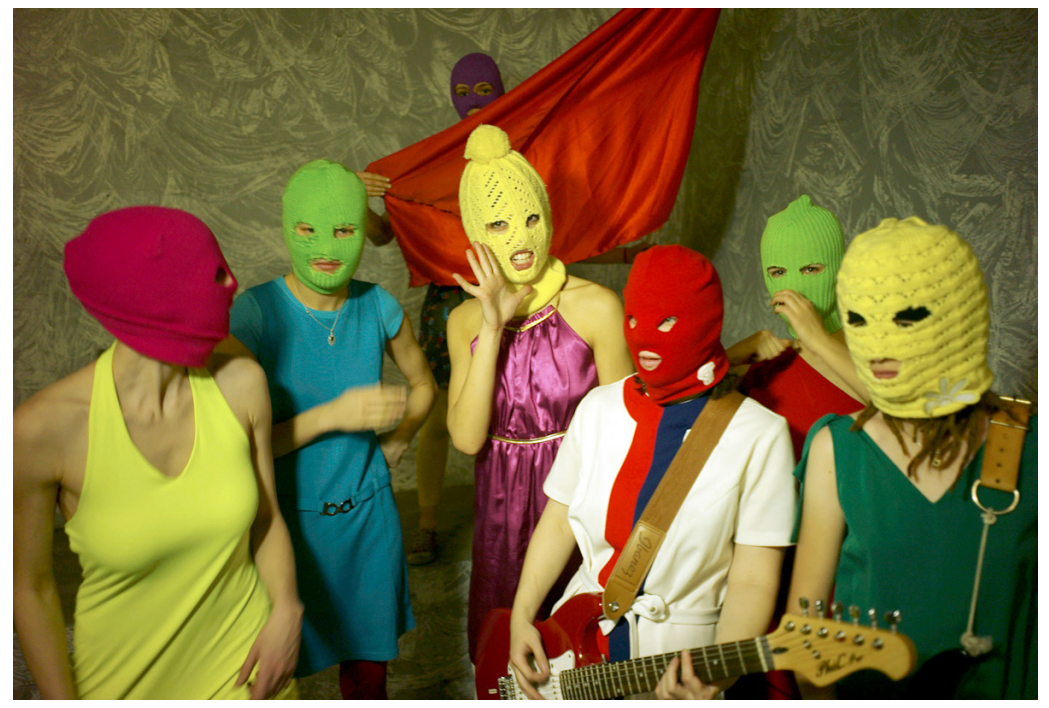

Pussy Riot, Moscow, 20I 2. Photographer: Igor Mukhin. Copyright Creative Commons Attribution-Share Alike 3.0 Unported license, CC-BY-SA. https://en.wikipedia.org/wiki/Pussy_Riot\#/media/File:Pussy_Riot_by_Igor_ Mukhin.jpg 


\section{Don't Be Quiet, Start a Riot! On Feminist Activist Performance}

On February 2I, 20I 2, a group of five young women calling themselves Pussy Riot appeared at the Cathedral of Christ the Savior in Moscow. Their guerrilla performance was part of a democracy movement focusing on human rights, freedom, and equality that continues to this day. A month after the above action the three members of Pussy Riot sat in a packed courtroom in Moscow. They were accused of hooliganism and anti-religious propaganda for performing their now world-famous punk prayer, "God save us from Putin."

In April of the following year a mute Vladimir Putin stood beside Angela Merkel at an industrial event in Germany. In the front of him bare-breasted women with slogans such as "Fuck Putin, dictator!" painted on their bodies were shouting. The rigidly composed Russian president did not know where to look. The startling action was perfectly timed, and the photographers present could not get enough of the show. However, this was not a Pussy Riot event. It was their Ukrainian colleagues, Femen, firing off one of their anti-Putin actions. A global audience was able to witness a political provocation by feminist activists because media technology relayed the event to the world.

Pussy Riot and Femen illustrate how contemporary transnational feminist activist performance theatricalizes a provocation in public space as an anarchistic method of directing attention to issues. It is no coincidence that the actions of Pussy Riot and Femen are theatrical and executed as performative events. The methods are old, but the immediate impact is new. Social media and modern technology provide these actions with the transnational visibility they never had before. As Judith Butler notes, gender is

How to cite this book chapter:

Rosenberg, Tiina 20I6. Don't Be Quiet, Start a Riot! On Feminist Activist Performance. In: Rosenberg, Tiina Don't Be Quiet, Start a Riot! Essays on Feminism and Performance. Pp. 21 8-238. Stockholm: Stockholm University Press. DOI: http://dx.doi.org/IO.I6993/baf.l. License: CC-BY 4.0 
performative, a certain kind of enactment. No one is first one's gender and then decides to enact it. Enactment is part of its ontology. ${ }^{\mathrm{I}}$

Pussy Riot's performance style and Femen's topless actions contain four elements characteristic of activist art: I) performance, 2) provocation, 3) location, and 4) manifestos. Pussy Riot chose the Cathedral of Christ the Saviour as the stage for its prayer to the Virgin Mary, imploring that Putin be ousted from power. Femen generally uses public spaces to stage their political actions. While this is accepted by most feminists, it has also created complications within the feminist movement. Femen, for example, has been accused of both Islamophobia and white, able-bodied Western dominance by Muslim feminists. Such conflicts have arisen from the open display of the naked body by protestors and the ensuing controversy over whether it is an appropriate direction for all feminists to take.

\section{Pussy Riot}

News of Russia appearing in Western media has been dominated by reports of corruption, a lack of democracy, Putin's increasingly authoritarian methods, the invasion and intimidation of neighboring states, and discrimination against minorities, especially LGBTQ people. ${ }^{2}$ The world witnessed how the Ukrainian revolution began in November 2013 when protestors occupied Maidan Square in Kiev. It was followed by a massacre that launched one of the most remarkable European political developments in recent memory. In February of the following year the Russians captured Crimea, a farcical referendum was held, and before people realized what was happening, the Crimean peninsula had become Russian again. Civil war broke out in $20 \mathrm{I}_{4}$ in the Ukraine, which since then has been unlike any other European country.

Civil society in Russia is strictly controlled, but it continues to thrive through various forms of everyday solidarity. Those who want to catch a glimpse of the new civil society in Moscow can look at the recently opened cafes, small publishers, groups of artists, and other alternative associations where a fresh spirit flourishes. Pussy Riot is a part of that growing scene. Founded in August 2OII, it is a Russian feminist art collective whose members prefer to remain anonymous. That anonymity was broken when three 
of its members, Maria Alyokhina, Nadezhda Tolokonnikova, and Yekaterina Samutsevich were arrested. Samutsevich was released, while Tolokonnikova was imprisoned at Correctional Colony Number 14 in Mordovia and Alyokhina at Correctional Colony Number 28 in the Urals until December 2013.

Since that time, members of Pussy Riot have campaigned for improved conditions in Russian prisons. They have also carried out activist interventions during the Sochi 20I4 Winter Olympics, where police herded them away. Responding to questions about why they chose to become political performance artists, Tolokonnikova stated that while it might be possible in the West to be an independent artist, Russian artists do not have the legal channels to freely express critical views. Pussy Riot was offered a world tour after their release, but they declined. In Words Will Break Cement: The Passion of Pussy Riot, Masha Gessen rejects labeling Pussy Riot colorful "punk girls." Instead, she sees them as a conscious part of the Russian democracy movement and an element in larger resistance efforts. ${ }^{3}$

\section{Femen}

While members of Pussy Riot are based in Moscow, Femen was founded in Kiev in 2008 by students protesting discrimination against women, poor prenatal care, sex tourism, trafficking, sexual harassment in the workplace, and other forms of sexism. Femen had originally intended to work on building civil society in the Ukraine, but moved its base to Paris when the recent political upheaval in the Ukraine made it impossible to remain there.

Widely known for its bare-breasted actions, the group has expanded over the years to several countries where members take issue with practices they perceive as unfair and misogynistic. Femen has always used performance to present its message. In a deliberate theatrical transnationalization of its political mission, Femen presents naked or half-naked women and men in its protests. In its outreach across the borders of nation states, the group's objective is total victory over patriarchy. It seeks to achieve this through its bare-breasted activism (which it terms "sextremism") by provoking patriarchy into open conflict; undermining its fundamental institutions (such as dictatorships); abolishing the sex industry and the 
church (both of which it sees as controlling and oppressing people); and creating an effective, worldwide feminist combat movement.

Rebecca Schneider, writing about the concept of the explicit body, states that feminist performance art accentuates the body in political purpose. ${ }^{4}$ In appearing topless, members of Femen use their bodies as scenes in which protest literally unfolds. Their slogans are written directly on bare skin to make a political point. However, another performance scholar, Peggy Phelan, cautions that visibility can entrap people by provoking voyeurism and fetishism. Because a colonial, imperialist hunger after ownership persists in our society, visibility remains a peculiar political enticement. ${ }^{5}$

By making its bodies explicit, Femen connects with the activist feminist tradition. Bodies are presented by Femen in such a way that they become provocative and confusing, something which might evoke hostility, but also empathy, from the audience. According to Femen's website, it sees itself as the premier force of feminism: its militant advance movement, and a contemporary incarnation of the free and fearless spirit of the Amazons. ${ }^{6}$ However, the group has also been accused of sensationalism and craving media attention. ${ }^{7}$ Critics deride Femen as young, white, able-bodied, topless exhibitionists who lack any ideological driving force. Femen, in turn, argues that in confronting men they use male sexist strategies, such as writing their messages on their breasts where men cannot help but read them.

\section{Anarchism revisited}

It is an open question whether the actions of Pussy Riot and Femen should be considered artistic performances with a political purpose, or political activity pursued through artistic means. Anarchism has become a point of departure in recent discussions on politics. In Gaga Feminism: Sex, Gender, and the End of Normal, J. Jack Halberstam reformulates the concept of revolution. Examining popular culture as embodied in Lady Gaga (including anarchism, surrealism, feminism, queer, and gender theory, as well as such social movements as Occupy Wall Street), Halberstam concludes that "going gaga" means something other than revolution as Karl Marx or Valerie Solanas would have defined it. The kind of revolution 
Halberstam has in mind is a contemporary way to connect a punk sort of anarchist feminism to stylize and express protests today.

As we have seen in the $20 \mathrm{II}$ riots, protests, and occupations happening around the world, especially in urban centers, we seem to have entered a new era of anticorporate anticolonial struggle in which the form matters as much as the content. No longer satisfied with simply marching or issuing a list of demands, these new movements turn politics into performance and combine anarchist mistrust of structure with queer notions of bodily riot and antinormative disruption. ${ }^{8}$

Using performance as a revolutionary method is not new. The theatricality of everyday life and public demonstrations are matters that scholars of performance studies have discussed for decades. The things that have happened in various parts of the world have revitalized transnational protest cultures and taken advantage of anarchist suspicions against capital and the state. Halberstam counters both traditional feminism and capitalism in conjuring up a vision of gaga feminism in which mom wants an anarchist revolution instead of an expensive new handbag. ${ }^{9}$

Butler, who focuses on human rights, ethics, and anti-war politics, has recently written on anarchism. ${ }^{\text {Io }}$ The letters of Emma Goldman, known for her anarchist political philosophy, have been published in a new edition. In Two Cheers for Anarchism, sociologist James C. Scott analyzes contemporary society from an anarchist perspective. ${ }^{\text {II }}$ In 2013 the Museum of Modern Art in New York City presented an exhibition entitled "PUNK: Chaos to Couture" in which underground, agitprop, and do-it-yourself (DIY) activism were all juxtaposed with made-to-measure fashions. The contributors to The Anarchist Turn, an anthology of papers from a 20I I conference of the same name at the New School for Social Research in New York City, try to convince readers that anarchy is in the air and that it is especially suited to our times. ${ }^{\mathrm{I}}$

The Arab Spring, the Occupy Movement in the US, antiausterity protests in Greece, pro-democracy demonstrations in Hong Kong, the fight of indigenous people for land, and the Blockupy Movement in Europe are all examples of contemporary 
global protest movements with anarchist agendas. ${ }^{13}$ Against this background, the connection between anarchism and feminist public protests such as Pussy Riot's punk prayer and Femen's actions is evident. The style, shock value, and to some extent the philosophy of these movements have similarities. Nina Gurianova writes that the relationship between concepts of culture and politics, and between aesthetics and anarchy, has changed radically over the past century. ${ }^{14}$ In a 1973 study entitled L'esthétique anarchiste, André Rezler was the first to develop a methodology that considers avant-garde aesthetics "anarchist," as opposed to Marxist interpretations of the arts. ${ }^{15}$

\section{Ontological anarchism and the avant-garde}

The performative roots of Pussy Riot and Femen may be found in the tradition of the Russian avant-garde and feminist performance. Gurianova's study, The Aesthetics of Anarchy: Art and Ideology in the Early Russian Avant-Garde, shows how Russians in the I9Ios were influenced by the nineteenth-century anarchism of Mikhail Bakunin and his idea of destructive creation. ${ }^{16}$ The root of the term anarchism comes from the Greek an (without) and arche (beginning or rule). Thus, an + archos means "without a ruler." The avant-garde's common denominator has been an aesthetic and philosophical ethos that Gurianova calls ontological anarchism, in contrast to political anarchism. The avant-garde developed in parallel with the revolutionary political movement that emerged in Russia just before World War I.

Ontological anarchism is anti-authoritarian and radically individualistic. It rejects the legacy of ready-made systems of thought in order to make space for creativity, but it does not endorse any specific political utopia. In Russia the avant-garde began with the formation of the artists association Bubnovi Valet (Jack of Diamonds), whose principal members were Mikhail Larionov and Natalia Goncharova. The latter challenged established notions of art in her search for a new national Russian style. Because she broke taboos, Goncharova was accused of pornography and blasphemy. Artists of the avant-garde deliberately shocked and provoked people by introducing unexpected gaps in the flow of 
words, images, or tones, forcing their audience to think and react, while offering them no final answers.

The avant-garde flourished in the atmosphere of strong political tensions as the war approached. In Russia an apocalyptic mood was intensified as a result of the country's political system, which had become increasingly authoritarian after the 1905 Revolution failed. Unlike political revolutionaries, the artists of the period were socially engaged. They followed no narrow political tradition, but thought that art should liberate a society stuck in old patterns of thought.

Most avant-garde artists supported the Bolshevik Revolution, but reacted quickly against restrictions placed upon freedom of expression, and they resisted political attempts to take control of cultural life. When that did happen, artists began to cooperate with political anarchists. Goncharova and others contributed articles to Anarkhia, the newspaper of the Moscow Federation of Anarchist Groups, whose first issue was published in I9I7. Anarkhia directly opposed the policies of the Bolsheviks in I9I8, and so the newspaper was shut down.

The avant-garde tradition of ontological anarchism remains alive in feminist performance. However, rather than revive the I9Ios avant-garde style, a common anarchist ethos was adopted that shocked and incited the public in order to challenge established ideas. With laughter, irony, parody, and taking things to extremes, contemporary feminist artists provoked the dismantling of power, along with its symbols and concepts.

\section{Russian Riot Grrrls}

"Hey Girlfriend, I got a proposition for you. It goes something like this: dare ya to do what you want, dare ya to be who you will, dare ya to cry right out loud," sings the group Bikini Kill in "Double Dare Ya." The Riot Grrrl movement, insofar as it can be considered a single movement, was born in the Pacific Northwest during the early I990s. Bikini Kill became one of its first and most famous bands. The movement encouraged young women to take their place in rock music without apologizing for their presence. As the phenomenon spread, a variety of fanzines and, later, webpages 
were founded by young angry Grrrls who created music with a furious sound. They developed an aesthetic that was to reclaim femininity with outfits consisting of stereotypical girlish features, including short doll dresses, lipstick, and Hello Kitty accessories.

The three members of Pussy Riot who are known through international media grew up sharing their frustration over the marginalization of feminism in post-Soviet society. Inspired by feminist theory and the Riot Grrrl movement, they founded the band Pisia Riot (pisia meaning pussy in Russian). They set lyrics addressing the daily struggles of women to a track from the British punk group Cockney Rejects, and called on women to rebel and kill sexists. In this way, the idea of Pussy Riot was born.

The Pussy Riot performance style combines mini-dresses and colorful balaclavas with and powerful, extroverted body language encoded in harsh (rather than classically feminine) tones and gestures. Their words are delivered in a style that approaches screaming, accompanied by kicks and flailing arm movements, while their politically conscious lyrics address feminism and sexual politics. The main enemies of Pussy Riot and Femen are Vladimir Putin and his authoritarian regime.

\section{Performing provocations}

Social movements have their specific aesthetic formats. These may be demonstrations, protests, guerrilla theater, music, poetry, visual arts, media events, or actions that play out in the streets. The concept of public space presupposes that a line is drawn between what is public and what is non-public. The same distinction applies to works of art, where we distinguish between public (generally outdoor) and private (indoor) art. The public sphere is a place where democracy can be exercised, with the government guaranteeing security. As public space has come under the control of politicians, social groups have relocated away from urban settings, although officials continue to describe those spaces as "available." Butler cites Hannah Arendt's comment that politics requires the space of appearance. Spaces make people explicit, and according to Butler we should rethink this notion: "In order to understand 
the power and effect of public demonstrations for our time, we will need to understand the bodily dimensions of action, what the body requires, and what the body can do, especially when we must think about bodies together, what holds them there, their conditions of persistence and of power." ${ }^{17}$

Pussy Riot maximized the visibility of their prayer action by choosing to stage it in a cathedral, knowing that their provocation would be filmed and quickly gain media attention, including their protest song. Its lyrics claim that if the Virgin Mary were alive today, she would become a feminist and denounce Putin. While the punk prayer of Pussy Riot contains the irreverent words "the Lord's shit," it regards the religious figures it invokes positively, in contrast to Putin and Patriarch Kirill of Moscow, whose secular name was Vladimir Mikhailovich Gundyaev. The Virgin Mary is petitioned as a feminist to save the people from Putin, and in the English version of the lyrics Patriarch Kirill is urged to withdraw his trust from Putin and place it in God instead. Pussy Riot's performance was a conscious public provocation whose consequences might have been anticipated.

\section{(Chorus)}

Virgin Mary, Mother of God, put Putin away, Put Putin away, put Putin away!

\section{(Petitioner)}

Black robe, golden epaulettes, All parishioners crawl and bow; The phantom of liberty is in heaven, Gay pride sent to Siberia in chains.

The head of the KGB, their chief saint, Leads protesters to prison under escort. In order not to offend His Holiness,

Women must give birth and love.

Shit, shit, the Lord's shit! Shit, shit, the Lord's shit! 
(Chorus)

Virgin Mary, Mother of God, become a feminist,

Become a feminist, become a feminist!

(Petitioner)

The church's praise of rotten dictators, The crossbearing procession of black limousines.

A teacher-preacher will meet you at school:

Go to class - bring him money!

Patriarch Gundyaev believes in Putin.

Bitch, better believe in God instead!

The belt of the Virgin can't replace mass meetings;

Mary, Mother of God, is with us in protest!

(Chorus)

Virgin Mary, Mother of God, put Putin away!

Halberstam stresses the meaning of popular culture and the performative strategies used in conjunction with public manifestations: songs, shows, poetry readings, chanted slogans, and other elements belonging to cultural demonstrations. Inspired by Lady Gaga's “Gaga Manifesto," in which a gagapocalypse was envisioned, Halberstam advocates not reform, but anarchist revolution - and preferably now. Halberstam states that while popular culture is often criticized for its superficiality and commercialism, those elements are the keys to understanding and liberating society as it is constituted today. ${ }^{18}$

\section{Manifestos}

Pussy Riot's prayer was a manifesto, the poetry of revolution rooted in the tradition of Marx and Engels, whose I 848 Communist Manifesto has been described as the single most influential text of the nineteenth century. Terry Eagleton has pointed out that very few thinkers have changed the course of history in such a decisive manner with a single document as Marx and Engels. ${ }^{19}$

In his history of manifestos, Martin Puchner notes that the genre began with Marx and Engels. Puchner finds that modern 
manifestos do not analyze the past; they wish to make history. ${ }^{20}$ A manifesto is an agonistic speech act that characterizes a monumental conflict and presents a radical utopian solution. Manifestos are both performative and theatrical acts, and are familiar to us from futuristic, Dadaist, and surrealist proclamations. The avant-garde of years past has performed and published a great number of manifestos, many of them satirical. Filippo Tommaso Marinetti wrote a futurist manifesto that was published in Le Figaro in 1909.

Examples of more recent manifestos connecting feminism with sexual politics are Valerie Solanas's S.C.U.M. Manifesto, a cult text of the I960s, whose famous opening words are "Life in this society being, at best, an utter bore and no aspect of society being at all relevant to women, there remains to civic-minded, responsible, thrill-seeking females only to overthrow the government, eliminate the money system, institute complete automation and destroy the male sex." ${ }^{21}$ Further examples of manifestos are "Queers Bash Back" by Queer Nation, "The Advantage of Being a Woman Artist" by Guerilla Girls, and "The Riot Grrrl Manifesto: Revolution Girl Style Now!” These texts were all born out of anger, although they avail themselves of humor and irony in order to make a political point. Halberstam invokes Lady Gaga's “Monster Mother's Manifesto" to push us further into the crisis, and quotes The Invisible Committee's slogan, "In a crisis, in this crisis, don't remain calm: get agitated and add to the chaos." 22

\section{The Topless Jihad Day}

Provocations, like spaces and manifestos, are complex matters. When Pussy Riot was accused of blasphemy they insisted that they were not against religion as such, but against organized religion and the Russian Orthodox Church. But actions can sometimes miscarry, and the feminist desire to create solidarity does not always succeed. Femen's ideology is based on sextremism, feminism, and atheism, and one dubious provocation was their call for a Topless Jihad Day in solidarity with the Tunisian activist Amina Sboui, who in March 2013 posted topless pictures of herself on Facebook with the text, "My body belongs to me." 
The idea behind a Topless Jihad Day was to launch an international campaign of unity and have topless women march through the streets of several European cities. Femen's initiative met with opposition by the Facebook page "Muslim Women Against Femen," which featured pictures of fully-clothed Muslim women with slogans like "Too cool to be oppressed" and "I do not need to be rescued." Sofia Ahmed, a Muslim feminist and student activist in Manchester, UK, was of the opinion that Femen's campaign was counterproductive and that the group was using stereotypes that expressed Islamophobic views of Muslim women. Femen countered that "You can use as many scarves as you wish, if you have the freedom to take them off when you wish and put them back on when you wish."

Another action, a hijab manifestation, was conducted in Sweden in the summer of 20I3. The campaign was aimed at everyone who normally does not wear a hijab, but was willing to do so for one day. Both women and men participated in this action. Even so there was a lively debate about whether a feminist defense of the hijab was possible. Others were critical of white middle-class people playing at being Muslims for a day and then returning to their own secure lives. Heated discussions over the veil showed that in a diverse society some people like to wear certain clothes, while others feel that wearing compulsory garments is an affront to their liberty.

Having relocated from Kiev to Paris, Femen International, as the organization is now called, operates in a country where a 2004 law has banned school children from wearing "explicit signs" of religious affiliation in the public schools. Although the law applies to all religious groups, it is primarily directed against Muslim girls wearing headscarves. Supporters of the law regard the veil as indicative of Islam's inability to modernize, and claim that upholding the ban defends France's secular and republican values.

In The Politics of the Veil, Joan Wallach Scott sharply rejects this approach. Based on an analysis of the issues that underlie the ban debate - racism, secularism, individualism, and sexuality she shows how, rather than facilitating coexistence between different religious and cultural groups, the law has exacerbated such divisions in French society. ${ }^{23}$ Scott and others who have studied the outrages of Islamophobia in the West since 9/I I believe that 
the traditional idea of national unity ("one size fits all") is no longer a viable model for Western democracies.

A new approach, in which diversity is accepted as a necessary component of national and transnational communities, is badly needed. Unfortunately, the political current in European politics is not going in that direction. Instead, there is a resurgence of neo-fascist and right wing populist parties fostering Islamophobic and anti-migrant agendas. Such parties have one thing in common: the dream of a mono-cultural nation, free from migrants, as their political utopia. Femen appears not to have realized how complex this political question is when they declared their vision of veil-free Muslim sisters.

\section{Feminist aesthetic strategies}

The avant-gardists of the early twentieth century were intent on destroying the bourgeois art marketplace that largely focused on selling art or finding artwork that was best suited to be exhibited in museums. Instead, they wished to replace the commercial art business with art activism that would have a direct impact on society and everyday life. Their artistic efforts were directed against social power structures and they thereby created a new aesthetics of the commonplace. They designed fashion, cars, furniture, and other objects of everyday life. Their aim was to create a totally new concept of art's place in human life.

Those ideas have since inspired generations of feminist artists. The legacy of the avant-garde, with its unconventional attention to ordinary phenomena, was a form of impure aesthetics that produced "ugly," fragmentary, and chaotic work. Such issues again emerged in the I960s as the Western world was moving into a new and radical era. From these beginnings a feminist avant-garde developed. Central to this emerging movement and its theoretical underpinnings were issues of representation, power, gender, and politics, but also the relationship between art and daily life.

Activists in the feminist tradition have employed naked protests before Femen appeared. Pioneers of body art, beginning with such artists as Carolee Schneeman, Hannah Wilke, and Yanoi Kusama, all performed bodily acts. Schneeman's Interior Scroll (I975) is a 
classic in which where she drew a long strip of paper containing a poem written to a structuralist filmmaker out of her vagina and read it aloud in performance. Other classic examples of body actions are Marina Abramovic's works Rhythm 2 and Rhythm o, both created in I974. In Rhythm 2 Abramovic took drugs and then gave her body to the audience in a state of vulnerability and passivity. In Rhythm o she experimented with passive aggression by standing on a table and offering her body to the audience along with razor blades, scissors, knives, needles, candles and other items to use in any way they wished. At the end of the performance her body was decorated with various accessories, but it was also damaged by sharp objects. A similar experience was presented in Yoko Ono's Cut Piece (1964), where she investigated passive aggression by letting the public cut up the clothing she wore on her body. The initially reserved crowd became more and more aggressive as the event progressed. The lesson to be drawn from Abramovic and Ono's early performances is that the cruel reactions those events elicited probably apply to audiences at large.

\section{Vulnerability}

Stacy Alaimo discusses corporeal feminist theories and material feminisms in relation to the many naked protests that have taken place worldwide. She sees the enacting of nakedness as an ethical performance of vulnerability, and uses the term trans-corporeality to emphasize the imbrications of human bodies - with one another, and with non-human creatures and physical landscapes. ${ }^{24}$ Protests such as those of Pussy Riot and Femen redefine modes of representation and gendered scenarios of visibility. Both groups act out vulnerability between human corporeality, geographical places, and networks of power. Like feminist body theorists Elizabeth Grosz and Elizabeth Wilson, Alaimo reconnects with the materiality of the body, literally with the "flesh."

The interpretation of subversive feminist bodily strategies in different art forms is highly context dependent. When protesters show their naked bodies, they expose their vulnerability from a political and ethical standpoint. Their human flesh and the indications of life it reveals are sensitive because of their bodily existence 
and presence. Using the group La Tigresa as an example, Alaimo states that naked protests are effective at directing attention to certain political issues. When protesters undress they challenge the limitations of being human for a brief period. Trans-corporeal ethics, according to Alaimo, is one way for feminist cultural studies to take these actions seriously, allowing us to seek a more complex and sustainable interpretation of the flesh we humans consist of and the places we live and move in. ${ }^{25}$

\section{On utopia}

Pussy Riot has made their voices heard through speeches, letters, and other written materials. Masha Gessen has interviewed members of the group and documented their trial. In $20{ }_{3} 3$ The Feminist Press in New York published Pussy Riot! A Punk Prayer for Freedom. Letters from Prison, Songs, Poems, and Courtroom Statements, Plus Tributes to the Punk Band that Shook the World. The book was issued in Pussy Riot's name, although not by the group. Publication rights were negotiated through Pussy Riot's attorneys Mark Felgin, Nikolai Plozovin, and Violetta Volkova. The book includes correspondence between Pussy Riot and their lawyers that was never intended for publication. Included in the collection is the now legendary performative speech act that Nadezhda Tolokonnikova delivered as her closing argument at the Moscow trial in August 20I2. She ended her testimony with the following statement:

In conclusion, I would like to read the words of a Pussy Riot song that, strange as it may seem, proved to be prophetic. We foresaw that "the head of the KGB and Chief Saint of the land would place the protesters under guard and take them to prison." Neither I myself, Alyokhina, nor Samutsevich were found to have powerful and stable affects, or other psychological values that could be interpreted as hatred toward anything or anyone. So, "Open all the doors, tear off your epaulettes. Come, taste freedom with us!"

That's it.

(Applause)

The judge (irritated): Ladies and gentlemen, we are not in a theater! ${ }^{26}$ 
The judge's admonition was an attempt to reestablish order in the courtroom. He feared it might be turned into a theater, a place of make-believe and illusion, although in fact trials tend to be theatrical by nature. The well-worn metaphor that the world is a stage and the notion of theatrum mundi have a seductive ability to let reality appear as theater, hence as a kind of play. Daily life and its ritualized situations may seem imbued with theatricality, although that does not mean they can be explained as theater. The exasperated judge wanted to show the world how Russia handles feminist rebels by sending them to penal institutions, a contemporary form of Gulag. ${ }^{27}$

Through the activist feminist tradition of our times we can hear the voice of Antigone resounding. She was an anti-authoritarian figure who might have stood as an anarchist role model if that tradition had had such figures. Although condemned to death, there was still power in her forceful protest. The present feminist revolution encompasses diverse political struggles and should be regarded as an unstable process through which change occurs. The politics of the everyday, trivial to some, are the foundation for protest movements today.

Jill Dolan and José Estaban Muñoz have both written about performing arts and utopia. ${ }^{28}$ The term utopia, from the Greek ou (not) and topos (place), i.e., "no place," was coined as the name of an imaginary land by Sir Thomas More in I 5 I6. Neither Dolan nor Muñoz describe the precise location or specific appearance of their future utopia. For them performance is an arena in which alternative worlds and experiences are created and can be communicated. Dolan calls this "militant optimism": keeping one's hope up, come what may.

Feminist activism has always used hi-volume provocative performance in spaces open to the public as a part of its militant optimism. The time spent in prison did not break Pussy Riot's spirit, and Femen continues its bare-breasted actions. It is both a conjecture and a hope that feminist artists and activists will continue to create material as vehicles for the urgent stories that need to be told. The anarchist approach, typical of our time, concentrates on resistance and processes; the objectives evolve from the action. The goals are thus indistinguishable from the method, and the outcome is less important than the process. 


\section{Notes}

I. Butler, "Bodies in Alliance," I 2.

2. Gessen, Words Will Break Cement and, by the same author, Man Without a Face; Hill \& Gaddy, Mr. Putin.

3. Gessen, Words Will Break Cement.

4. Schneider, Explicit Body.

5. Phelan, Unmarked.

6. www.femen.org

7. "Muslim Women Against Femen,” www.facebook.com

8. Halberstam, Gaga Feminism, I33.

9. Ibid.

ıo. Butler, "Palestine."

I I. Scott, Two Cheers for Anarchism.

I2. Blumenfeld, Bottici, \& Critchley, Anarchist Turn.

I3. van Gelder, This Changes Everything. See also Graeber, Direct Action and, by the same author, The Democracy Project.

I4. Gurianova, Aesthetics of Anarchy, 7.

I 5. Ibid., 9; Reszler, L'esthétique anarchiste.

I6. Gurianova, Aesthetics of Anarchy; Jonson, "Pussy Riots metoder." I7. Butler, "Bodies in Alliance," 2.

I 8. Halberstam, ix-x.

19. Eagleton, Why Marx was Right.

20. Marx \& Engels, Communist Manifesto, "Introduction”.

2I. Solanas, “S.C.U.M Manifesto.”

22. Halberstam, Gaga Feminism, I33.

23. Scott, Politics of the Veil.

24. Alaimo, “Trans-Corporeal Ethics.” See also Reilly \& Nochlin, Global Feminisms.

25. Alaimo, “Trans-Corporeal Ethics,” 35. 
26. Pussy Riot! ı03; Tolokonnikova, Slutplädering, 3 I-32.

27. Ibid.

28. Dolan, Utopia; Muñoz, Cruising Utopia.

29. Boden, "Femen in på livet."

\section{Works Cited}

Alaimo, Tracy. "The Trans-Corporeal Ethics of the Protesting Body." Women \& Performance: A Journal of Feminist Theory 20 (2010): I 5-36.

Blumenfeld, Jacob, Chiara Bottici, and Simon Critchley, eds. The Anarchist Turn. New York: Pluto, $20 \mathrm{I} 2$.

Blumenkranz, Carla, Keith Gessen, Mark Greif, Sarah Leonard, and Sarah Resnick, eds. Occupy!: Scenes from Occupied America. New York: Verso, 20I I.

Bodin, Anna. "Femen in på livet" (Down to the Skin in Femen). Nyheter Lördag, I 5 Nov 2014.

Butler, Judith. "Palestine, State Politics and the Anarchist Impasse." In The Anarchist Turn, edited by Jacob Blumenfeld, Chiara Bottici, and Simon Critchley, 203-24. New York: Pluto, 2012.

. "Bodies in Alliance and the Politics of the Street." \#Occupy Los Angeles Reader I-3 (2OII): 2-I 2 .

Dolan, Jill. Utopia in Performance: Finding Hope at the Theater. Minneapolis: University of Minnesota Press, 2005.

Eagleton, Terry. Why Marx was Right. New Haven: Yale University Press, 20I I.

Gessen, Masha. The Man Without a Face: The Unlikely Rise of Vladimir Putin. New York: Riverhead, 20I3.

Words Will Break Cement. The Passion of Pussy Riot. New York: Riverhead, 20I4.

Graeber, David. Direct Action. An Ethnography. Oakland, CA: AK Press, 2009.

. The Democracy Project. A History. A Crisis. A Movement. London: Penguin, 2013. 
Gurianova, Nina. The Aesthetics of Anarchy: Art and Ideology in the Early Russian Avant-Garde. Berkeley: University of California Press, 20I 2.

Halberstam, J. Jack. Gaga Feminism: Sex, Gender, and the End of Normal. New York: Beacon Press, $20 \mathrm{I} 2$.

Hill, Fiona, and Clifford Gaddy. Mr. Putin: Operative in the Kremlin, Washington, DC: Brookings Institution, 20I3.

Jonson, Lena. "Pussy Riots metoder har gamla anor" ("Pussy Riot's Methods Are Not New"). Svenska Dagbladet, I7 Aug 2012.

Marx, Karl, and Friedrich Engels. The Communist Manifesto and Other Writings by Karl Marx, Friedrich Engels. Introduction and Notes by Martin Puchner. New York: Barnes and Noble, 2005.

Muñoz, José Estaban. Cruising Utopia: The Then and There of Queer Futurity. New York: New York University Press, 2009.

Phelan, Peggy. Unmarked: The Politics of Performance. London: Routledge, I993.

Pussy Riot! A Punk Prayer for Freedom: Letters from Prison, Songs, Poems, and Courtroom Statements, Plus Tributes to the Punk Band that Shook the World. New York: Feminist Press, 20I3.

Reilly, Maura, and Linda Nochlin, eds. Global Feminisms: New Directions in Contemporary Art. London: Merrell, 2007.

Remmets, Anna. "Kritik mot Putinstyre fick punkbönens form" ("Critic Against Putin got the Shape of a Punk Prayer"). Arbetaren 35 (2OI4): IO-II.

Rezler, André. L'esthétique anarchiste. Paris: Presses universitaires de France, 1973.

Schneider, Rebecca. The Explicit Body in Performance. London: Routledge, I997.

Scott, James C. Two Cheers for Anarchism: Six Easy Pieces on Autonomy, Dignity, and Meaningful Work and Play. Princeton, NJ: Princeton University Press, 2012.

Scott, Joan Wallach. The Politics of the Veil. Princeton, NJ: Princeton University Press, 2007. 
Solanas, Valerie. S.C.U.M. Manifesto. Oakland, CA: A.K. Press, 2013 [I968].

Tolokonnikova, Nadezhda. Slutplädering. Stockholm: Norstedts, 20I2. [Tolokonnikova's closing argument from the Pussy Riot trial in Swedish translation.]

van Gelder, Sarah, ed. This Changes Everything: Occupy Wall Street and the 99\% Movement. San Francisco: Berrett-Koehler, 20 I I.

\section{Homepages}

www.femen.org

www.freepussyriot.org

“Muslim Women Against Femen,” www.facebook.com

www.womynkind.org 